\title{
Life cycle analysis of potential municipal solid wastes management scenarios in Tanzania: the case of Arusha City
}

\author{
Edwin N. Richard ${ }^{1,2^{*}}$ D, Askwar Hilonga ${ }^{3}$, Revocatus L. Machunda ${ }^{1}$ and Karoli N. Njau ${ }^{1}$
}

\begin{abstract}
The municipal solid wastes (MSW) management technologies in most cities of developing countries pose a continuous risk of contaminating the environment and affecting human health adversely; often because MSW technologies are not comprehensively analyzed before their implementation. For this purpose, the life cycle assessment methodology was applied to access the different MSW management scenarios in Arusha City, Tanzania. Three different scenarios of recycling and sanitary landfilling (RSL) were developed as the business as usual scenario (RSL) (SN-1), RSL combined with composting (SN-2), and RSL combined with anaerobic digestion (SN-3). Results obtained showed that no scenario performed better in all impact categories, however with the current focus on climate change and limited funds in developing countries, the best option would be SN-2. The SN-2 which is the combination of recycling, composting and the landfill had the least economic cost and environmental burdens in most categories when compared to the other scenarios. The sensitivity analysis results indicated that improving diesel consumptions, reducing methane emissions to air and increasing the recycling rate of papers and plastics would reduce the total environmental impacts on all scenarios.
\end{abstract}

Keywords: Arusha city, Economic, Environment, Impact factors, Life cycle assessment, Municipal solid wastes

\section{Introduction}

The municipal solid wastes (MSW) management in most cities of developing countries is still unsatisfactory despite several efforts to tackle it squarely. MSW management involves the collection and transport of waste, recovery of useful materials, and final disposal. These steps can lead to negative environmental impacts such as the release of greenhouse gases. For instance, by the year 2016, about $1600 \mathrm{Mt}$ of carbon dioxide equivalent $\left(\mathrm{CO}_{2}\right.$-equivalent $)$ greenhouse gas emissions were being generated from MSW annually, worldwide [1]. The life cycle assessment (LCA) tool is very crucial for evaluation

\footnotetext{
* Correspondence: richarde@nm-aist.ac.tz

'Department of Water and Environmental Science and Engineering, Nelson Mandela African Institution of Science and Technology, 23311 Arusha,

Tanzania

2Department of Water Resources Engineering, University of Dar es Salaam,

16103 Dar es Salaam, Tanzania

Full list of author information is available at the end of the article
}

and comparison of environmental burdens caused by different treatment options along with the entire life cycle treatment of the activity, process or product [2].

With the LCA tool, extensive studies on environmental impact assessment of MSW have been conducted worldwide. Khandelwal et al. [3] compared landfilling and the combinations of the different treatment options such as material recovery facility (MRF), composting, and anaerobic digestion in Nagpur city, India using LCA tool. The results of the study indicated that the combination of the MRF, landfill and composting has lower environmental impacts on most impact categories assessed compared with the other combinations of MRF with anaerobic digestion. Oyoo et al. [4] compared four different waste management scenarios in Kampala city of Uganda: open dumping and composting, landfilling, combining composting, recycling and the landfill, combining anaerobic digestion, composting, recycling and the landfill. It

(c) The Author(s). 2021 Open Access This article is licensed under a Creative Commons Attribution 4.0 International License, which permits use, sharing, adaptation, distribution and reproduction in any medium or format, as long as you give appropriate credit to the original author(s) and the source, provide a link to the Creative Commons licence, and indicate if changes were made. The images or other third party material in this article are included in the article's Creative Commons licence, unless indicated otherwise in a credit line to the material. If material is not included in the article's Creative Commons licence and your intended use is not permitted by statutory regulation or exceeds the permitted use, you will need to obtain permission directly from the copyright holder. To view a copy of this licence, visit http://creativecommons.org/licenses/by/4.0/. 
was concluded that the last one is the best for all impact categories assessed. Another study was carried out by Dong et al. [5] who compared three treatment alternatives in Hangzhou, China; landfill with energy recovery, landfill without energy recovery and incineration with the energy recovery. The best alternative concluded was incineration with energy recovery.

Therefore, different MSW technologies have been selected via the LCA tool that best suits the local conditions of the concerned area. The difference in results is due to many factors including data used, decision to include or not to include equipment which causes emissions, system boundaries considered in the analysis and local conditions of the concerned study area [6]. Also, MSW in developing countries has high organic content and lower calorific values as compared to the wastes in developing countries [7], and as such previous studies in developed countries cannot be generalized in subSaharan Africa where LCA studies are limited. In Tanzania specifically, the LCA applications for MSW decision making are yet to be applied and there is no single study on LCA on MSW that have been published in a peer-reviewed journal. Kazuva et al. [8] assessed the best MSW treatment options in Dar es Salaam City, Tanzania using a multi-criteria analysis approach Elimination and Choice Expressing Reality (ELECTRE). The ELECTRE decision-making tool aids the decision-makers to select best alternatives scenarios from several possible alternatives which are outranked by others in a selection $[9$, 10]. However, the study above [8] focused only on $\mathrm{CO}_{2}$ emissions as an environmental factor and thus further studies are required for correct interpretation since emissions such as methane, ammonia, nitrogen oxides, particulate matter just to mention a few are also likely to be impacted by MSW. Besides, previous LCA study described above [4], that could present the similar situation in Tanzania did not focus on several impact categories such as freshwater eutrophication, particulate matter formation and freshwater ecotoxicity which are also likely to be impacted by MSW. The present study aims at comparing the environmental impacts of different waste management scenarios for Arusha City, Tanzania. In Arusha City, the waste management practices include; recycling and sanitary landfilling even though organic waste fraction comprises a higher percent $(67 \%)$ which would require other options such as composting or anaerobic digestion. In our work three scenarios were analyzed which include; the business as usual scenario (BAU) of recycling and landfilling (SN-1), recycling and composting combining with landfilling (SN-2), recycling and anaerobic digestion combining with landfilling (SN3). The environmental impact categories considered in this study include climate change, photochemical oxidant formation, freshwater eutrophication, terrestrial acidification, freshwater ecotoxicity, terrestrial ecotoxicity, human toxicity and particulate matter formation.

\section{MSW management in the study area}

Arusha city is located in the northeast of Tanzania and is divided into 25 wards of which the collection of MSW is made. In Arusha city, the private companies and the community-based organization do the collections of the MSW from 25 wards and transport the wastes at the Muriet sanitary landfill for the disposal. The Muriet landfill site is allocated about $6.5 \mathrm{~km}$ from the City Centre and has been in operation since January 2019. This newly constructed landfill has the provisions for the landfill gas collection and leachate collections. At the landfill, about 400 registered waste pickers do the separation and collection of the recyclable materials and sell them at nearby landfill pre-processing centers. The city generates about $271 \mathrm{t} \mathrm{d}^{-1}$ with the waste compositions of $67 \%$ organic, $11 \%$ papers, $7 \%$ plastics, $6 \%$ textiles, $4 \%$ glass, $4 \%$ ashes and $1 \%$ metals, with an average moisture content of 59.8\% [11]. The high organic content suggests that biological treatment options such as composting and anaerobic digestion would be suitable for life cycle analysis in this city. Other proposed treatment facilities such as composting and anaerobic digestion are also assumed to occur at the same site.

\section{Materials and methods}

The LCA of the study was conducted as per the methodology described in ISO 14040 [12]. The ISO 14040 LCA methodology considers four main steps including; goal and scope definition, lifecycle inventory, life cycle analysis and interpretation. The ReCiPe 2008 Midpoint (H) V1.13 method was used to calculate the results because Umberto LCA software used in the analysis was using the ecoinvent version 3.6 [13] of which ReCiPe 2008 Midpoint (H) V1.13 is one of the few updated methods.

\section{Goal and scope definition}

This study aimed to analyze and compare the impacts on the environments due to MSW management scenarios through the use of the life cycle methodology in such a way that could promote the more suitable waste management option. The life cycle considered is the end of life stage of which materials becomes wastes when its values cease and therefore are collected for treatment and disposal. In the analysis, we also considered the "zero burden assumption" of which upstream environmental burdens were not included in the analysis. The functional unit considered to analyze and compare the alternative scenarios is based on one metric ton of MSW of Arusha city, Tanzania. In this study, two new proposed scenarios and existing scenario (BAU) for MSW practices of Arusha, Tanzania were analyzed and 
compared. Figure 1 shows the system boundary which includes MSW, inputs of materials and energy, and outputs like air and water emissions, fertilizers (compost and digestate), electricity generated from anaerobic digestion and landfilling process. The recyclable materials are placed outside the system boundary and their emissions are excluded in the analysis. This is because they are common to all scenarios and the consumers of the recycled scraps bear the burdens of recycling activities. Based on this proposed system boundary, Table 1 depicts the summary of the scenarios studied. Scenario (SN-1): The BAU (RCL_LF) Scenario presents currently practice for the MSW management in Arusha city of Tanzania. The MSW collected in the city are transported for the disposal at Muriet Landfill whereas recyclable materials (14.2\%) including paper/cardboard, metals, plastics and glass are recovered by the waste pickers and the rest of the wastes $(85.8 \%)$ are landfilled. Currently, there is no operating burning unit for reducing the volume of the wastes that are landfilled. Since the Muriet landfill is nearing people residences and has approximately 400 registered waster pickers, the burning units are also excluded in the proposed alternatives since could have immediate effects on people's health.

Scenario (SN-2): This scenario (RCL_CP_LF) assumes recyclable materials $(14.2 \%)$ are recovered by waste pickers as per current status, but $67 \%$ which is organic wastes are composted, and the residue wastes
(18.8\%) are landfilled. The composting process is assumed to be carried out in a batch-wise operation where the wastes will be placed in large piles and turning of the windrows will be accomplished through the use of the turning machines. Scenario (SN-3): This scenario (RCL_AD_LF) assumes recyclable materials $(14.2 \%)$ are recovered by waste pickers as per current status, but $67 \%$ which is organic wastes is treated in the anaerobic digestion process, and 18.8\% of the residue wastes are landfilled. Following Igoni et al. [14], the batch digester systems are recommended for the production of biogas from large amounts of MSW since they are very economical in terms of operations. For this economic reason in our study, we considered the anaerobic digestion process to occur in a batch process. Due to high moisture content (59.8\%) of Arusha MSW, the waste incineration option was not considered.

\section{Life cycle inventory}

Inventory data related to the study were calculated through various means including; personal calculations from MSW compositions of the study area, personal communications with Marco Chacha and James Lobikoki who are responsible for MSW management of Arusha City, on-site investigations at the landfill, markets places, MSW pre-processing centers and through various published works of literature. The Umberto LCA+ software library and ecoinvent 3v6 database (Accessed from Michigan server of

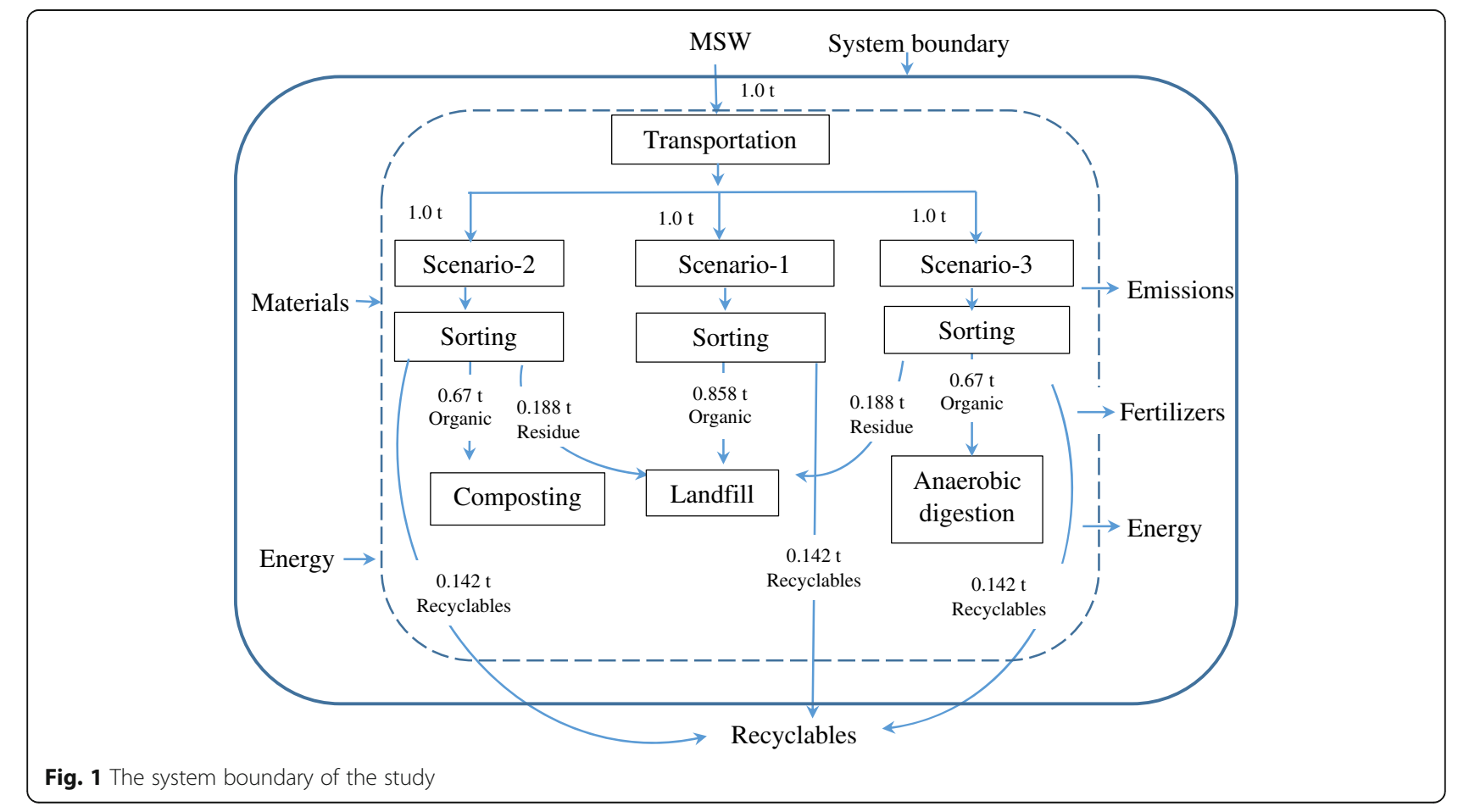


Table 1 Description of the considered scenarios for the life cycle assessment

\begin{tabular}{ll}
\hline Scenario & Description \\
\hline SN-1 (BAU) (RCL_LF) & $14.2 \%$ Recycled $(1.6 \%$ glass, $0.8 \%$ metals, $5.5 \%$ papers, $6.3 \%$ plastics $)+85.8 \%$ Landfilling \\
& $(67 \%$ organic, $8 \%$ ashes, $2.4 \%$ glass, $0.2 \%$ metals, $5.5 \%$ papers, $0.7 \%$ plastics, $2 \%$ textiles $)$ \\
SN-2 (RCL_CP_LF) & $14.2 \%$ Recycled $(1.6 \%$ glass, $0.8 \%$ metals, $5.5 \%$ papers, $6.3 \%$ plastics $)+67 \%$ Composting \\
& $(67 \%$ organic) $+18.8 \%$ Landfilling $(8 \%$ ashes, $2.4 \%$ glass, $0.2 \%$ metals, $5.5 \%$ papers, $0.7 \%$ plastics, $2 \%$ textiles $)$ \\
SN-3 (RCL_AD_LF) & $14.2 \%$ Recycled (1.6\% glass, $0.8 \%$ metals, $5.5 \%$ papers, $6.3 \%$ plastics) $+67 \%$ Anaerobic Digestion \\
& (67\% organic) $+18.8 \%$ Landfilling ( $8 \%$ ashes, $2.4 \%$ glass, $0.2 \%$ metals, $5.5 \%$ papers, $0.7 \%$ plastics, $2 \%$ textiles)
\end{tabular}

SN Scenario, BAU Business, as usual, RCL: Recycling, LF: Landfilling, CP: Composting, AD: Anaerobic digestion

USA) were used to supply the rest of the information necessary for this study. Table 2 indicates the inventory data under each scenario used in this study $[13,15-20]$.

\section{Waste transportation}

The estimated distance per ton of the study area that is required as input to the Umberto software for the life cycle analysis is based on $7.5 \mathrm{t}$ trucks (54 Nos, loaded with $5 \mathrm{t}$, return empty) transporting the wastes at about $6.5 \mathrm{~km}$ daily. The transport truck "Transport, freight, lorry, 3.5-7.5, metric ton" was selected from ecoinventv3 database of the Umberto LCA software.

\section{Recycling}

The recycling of the recyclables materials is expected to occur at the existing sanitary landfill. In recycling activities, the manual sorting of waste was considered instead of the material recovering facility due to the

Table 2 Inventory data under each scenario per ton of MSW

\begin{tabular}{|c|c|c|c|c|c|}
\hline Parameters & Unit & SN-1 & SN-2 & SN-3 & Ref. \\
\hline \multicolumn{6}{|l|}{ Foreground data } \\
\hline \multicolumn{6}{|l|}{ Avoided products } \\
\hline Electricity & kWh & 43.55 & - & 137.3 & {$[13,15,16]$} \\
\hline Fertilizer (N) & $\mathrm{kg}$ & - & 0.34 & 0.42 & \\
\hline Fertilizer (P) & $\mathrm{kg}$ & - & 0.40 & 0.22 & \\
\hline Fertilizer (K) & $\mathrm{kg}$ & - & 1.94 & 0.33 & \\
\hline \multicolumn{6}{|l|}{ Background data } \\
\hline Electricity consumption & kWh & 0.42 & - & 2.95 & [17-19] \\
\hline Diesel & $\mathrm{L}$ & 2.574 & 0.8789 & 0.564 & \\
\hline \multicolumn{6}{|l|}{ Emissions } \\
\hline Particulates, $<10 \mu \mathrm{m}$ & g & 0.75 & 0.75 & 0.20 & [19] \\
\hline Sulphur dioxide $\left(\mathrm{SO}_{2}\right)$ & g & 0.17 & 0.17 & 2.01 & \\
\hline Nitrogen oxides (NOx) & g & 7.44 & 39.40 & 127.30 & [20] \\
\hline Total Nitrogen (TN) & $\mathrm{kg}$ & 2.85 & & & \\
\hline Total Phosphorus (TP) & $\mathrm{kg}$ & 4.50 & & & \\
\hline Methane $\left(\mathrm{CH}_{4}\right)$ & $\mathrm{kg}$ & 55 & 0.83 & 8.98 & This study \\
\hline Ammonia $\left(\mathrm{NH}_{3}\right)$ & $g$ & 3.35 & 1271.2 & 714.0 & This study \\
\hline
\end{tabular}

SN1: Scenario 1; SN2: Scenario 2; SN3; Scenario 3 presence of the registered waste pickers in the study area. We also applied an allocation strategy in which the burdens of recycling activity are allocated to the consumers of the recycled scraps, and therefore their emissions were not included in the life cycle inventory analysis [6].

\section{Composting}

In this study, it is assumed that windrow composting will be employed. The decomposition of the organic matter and diesel requirements by the turning machines during composting process contribute to the greenhouse gas emissions. In most literature typical diesel requirements in windrow composting by turning equipment is estimated at $0.47 \mathrm{~L} \mathrm{t}^{-1}$ of waste [18]. The total amount of carbon and nitrogen present in a metric ton of the compostable wastes was estimated from MSW compositions of the study area (Table 3). The total amount of carbon and nitrogen present in a wet metric ton of wastes (67\% organic wastes) were calculated as $151.4 \mathrm{~kg}$ $\mathrm{C}$ and $6.5 \mathrm{~kg}-\mathrm{N}$ per wet mass respectively. Literature suggests that about $50 \%$ each of carbon and nitrogen are degraded for the production of the mature compost [16], and so we adapted the same percentage in our calculations. We computed the methane emission as $1.1 \%$ of the fraction degraded carbon during the composting process [21]. We also computed the ammonia emission as $19.5 \%$ of the total nitrogen presents in a compostable waste [22]. Other emissions were obtained from the literature. Umberto LCA+ software and ecoinvent v3.6 database were used to supply the indirect emissions of the diesel consumption by equipment during the composting process. The ReCiPe 2008 Midpoint (H) V1.13 methodology was applied to obtain their emissions. Since the biowaste of the study area comprises of 55\% food wastes and $45 \%$ garden wastes, which are similar to compositions of waste as per Boldrin et al. [16],

Table 3 Moisture and major elemental composition (\%) of the typical wastes in the study area [9]

\begin{tabular}{llllllll}
\hline Moisture & $\mathbf{C}$ & $\mathbf{H}$ & $\mathbf{O}$ & $\mathbf{N}$ & $\mathbf{S}$ & $\mathbf{C l}$ & $\mathbf{P}$ \\
\hline 59.79 & 56.20 & 5.42 & 35.49 & 2.42 & 0.31 & 0.05 & 0.11 \\
\hline
\end{tabular}


the estimates of the average value of $0.34 \mathrm{~kg}-\mathrm{N}, 0.40$ $\mathrm{kg} \mathrm{P}$ and $1.94 \mathrm{~kg}-\mathrm{K}$ of inorganic fertilizers are assumed to be recovered per one metric ton of MSW during the composting process. The recovered nutrients are assumed to bring the benefit of avoided production of the fertilizers. The leachates produced during the composting process are assumed to be recycled back in the process and therefore emissions in water were not considered.

\section{Anaerobic digestion}

When organic matter is degraded under anaerobic digestion it releases methane and carbon dioxide in larger percent including the lower percentages of hydrogen, hydrogen sulphide, ammonia, and siloxanes, aromatic and halogenated compounds [23]. To quantify emissions in the anaerobic digestion process we adapted the modified Buswell equation [24].

$$
\begin{aligned}
\mathrm{C}_{\mathrm{a}} & \mathrm{H}_{\mathrm{b}} \mathrm{O}_{\mathrm{c}} \mathrm{N}_{\mathrm{d}} \mathrm{S}_{\mathrm{e}} \\
+ & (\mathrm{a}-0.25 \mathrm{~b}-0.5 \mathrm{c}+0.75 \mathrm{~d}+0.5 \mathrm{e}) \mathrm{H}_{2} \mathrm{O} \\
= & (\mathrm{a}+0.125 \mathrm{~b}-0.25 \mathrm{c}-0.375 \mathrm{~d}-0.25 \mathrm{e}) \mathrm{CH}_{4} \\
& +(\mathrm{a}-0.125 \mathrm{~b}+0.25 \mathrm{c}+0.375 \mathrm{~d}+0.25 \mathrm{e}) \mathrm{CO}_{2} \\
& +\mathrm{d} \mathrm{NH} \mathrm{NH}_{3}+\mathrm{e} \mathrm{H} \mathrm{H}_{2} \mathrm{~S}
\end{aligned}
$$

The typical elemental composition of the Arusha MSW is shown in Table 3, and the molecular equation was calculated from dividing the elemental compositions and atomic weights of the elements. Hence, for one metric ton of the waste to be digested, the biodegradable waste would be about $670 \mathrm{~kg}$ (67\%). It contained C: $376.5 \mathrm{~kg}, \mathrm{H}: 36.3 \mathrm{~kg}, \mathrm{O}: 237.8 \mathrm{~kg}, \mathrm{~N}: 16.2 \mathrm{~kg}$, and S: $2.1 \mathrm{~kg}$ and the molecular equation for emission were obtained as;

$$
\begin{aligned}
\mathrm{C}_{31.4} \mathrm{H}_{36.3} \mathrm{O}_{14.9} \mathrm{~N}_{1.2} \mathrm{~S}_{0.1} & +15.82 \mathrm{H}_{2} \varphi 2 \neq 16.04 \mathrm{CH}_{4} \\
& +15.36 \mathrm{CO}_{2}+1.2 \mathrm{NH}_{3} \\
& +0.1 \mathrm{H}_{2} \mathrm{~S}
\end{aligned}
$$

From the molecular equation and the computation, about $257 \mathrm{~kg} \mathrm{CH}_{4}$ and $676 \mathrm{~kg} \mathrm{CO} 2$ were obtained and since the complete digestion depends on many factors, hence the complete digestion may not be achieved, the proportionality factor of 0.7 was used to adjust the value and hence about $\left(180 \mathrm{CH}_{4} \mathrm{~kg}\right.$ and $\left.473 \mathrm{~kg} \mathrm{CO}_{2}\right)$ are obtained. We assumed that 5\% (9.0 $\mathrm{kg}$ ) of methane is not captured for electricity generation and hence contributing to the emissions in the environment as per Belboom et al. [25]. Kaza and Bhada-Tata [15] indicated an electrical potential recovery per ton of MSW in anaerobic digestion to be in the range of $165-245 \mathrm{kWh}$. In this study, we adapted an average value of $205 \mathrm{kWh}$ and electricity consumption of $4.4 \mathrm{kWh}$ per metric ton of MSW.
With the current under-construction Rufiji hydroelectric power in Tanzania which has the capacity of $2115 \mathrm{MW}$, the main source of energy in Tanzania considered in the analysis is hydro-electric power [26]. Electricity consumption in the anaerobic digestion process is due to refining the waste ready for the digestion process. From ecoinvent database of Umberto software used, the application of the digestate for fertiliser use provides the nutrients of; $\mathrm{N}: 0.629 \%$, $\mathrm{P}_{2} \mathrm{O}_{5}: 0.331 \%$ and $\mathrm{K}_{2} \mathrm{O}: 0.495 \%$ per $\mathrm{kg}$ of fresh digestate. Therefore, with the assumption that processing one metric ton of organic matter in anaerobic digestion process generates about $100 \mathrm{~kg}$ of digestate [3], about $0.42 \mathrm{~kg}-\mathrm{N}, 0.22 \mathrm{~kg} \mathrm{P}$ and $0.33 \mathrm{~kg}-\mathrm{K}$ are assumed to be recovered per one metric ton of MSW during the digestion process.

\section{Landfill}

Emissions in a landfill can be attributed by the degradation of the organic matter as well as diesel requirements by vehicles used in the compaction of the wastes. To quantify the amounts of methane and carbon dioxide, we adapted the generalized equation bellow [18]:

$$
\begin{aligned}
& \mathrm{CH}_{4} \text { emissions }\left(\mathrm{kg} \mathrm{t}^{-1} \text { of MSW }\right) \\
& \quad=\mathrm{MSW}_{\mathrm{L}} * \mathrm{MCF} * \mathrm{DOC} * \mathrm{DOC} \mathrm{F}_{\mathrm{F}} * \mathrm{~F} *(16 / 12-\mathrm{R}) *(1-\mathrm{OX})
\end{aligned}
$$

where $\mathrm{MSW}_{\mathrm{L}}$ is the wet weight of the MSW disposed at the landfill. The MCF refers to the methane correction factor and ranges between 0.4 and 1 for unmanaged and managed well landfills [27]. We adapted the average values of 0.7 , because in most developing countries the landfills may not be perfectly managed. DOC is the percentage of the degradable organic carbon in wet waste and $\mathrm{DOC}_{\mathrm{F}}$ is the fraction of the degradable carbon that converts to the landfill gas through waste decomposition. In the study area, the DOC of the landfilled waste comprises of food waste $37 \%$, garden and wood $30 \%$, and papers $11 \%$ (Landfilled 5.5\%). By considering the typical composition of each organic wastes to be landfilled and estimated $\mathrm{DOC}_{\mathrm{F}}$ for waste component (Food waste $=0.64$, wood waste $=0.21$ and papers $=0.37$ ) as measured by Biochemical methane potential test [27], the $\mathrm{DOC}_{\mathrm{F}}$ of the waste composition in the study area was estimated at 0.41 . The value $16 / 12$ is the carbon content of methane, $\mathrm{F}$ refers to the methane concentration in landfill gas, $\mathrm{R}$ is the recovered methane fraction and $\mathrm{OX}$ is methane oxidation factor and were estimated as $\mathrm{F}=50 \%, \mathrm{R}=50 \%, \mathrm{OX}=36 \%$ ) [28]. From the computation, about $55 \mathrm{~kg} \mathrm{CH}_{4}$ are estimated as emissions to the environment. During the compaction process of the wastes in a landfill, about $3 \mathrm{~L}$ of diesel fuel $\mathrm{t}^{-1}$ of MSW are utilized [29]. To process one metric ton of MSW in 
a landfill an electricity consumption of $0.42 \mathrm{kWh} \mathrm{t}^{-1}$ of MSW would be required of which electrical potential recovery is estimated at $65 \mathrm{kWh} \mathrm{t}^{-1}$ of MSW $[15,17]$. Inventory data and their associated emissions due to recyclable materials such as scrap metals, glass, plastic wastes that are landfilled were obtained from ecoinvent v3.6 database embedded in Umberto LCA software. As the study adopted the same percentages of $18.8 \%$ of the recyclables materials that are landfilled in all scenarios, the impacts of their emissions are the same in all scenarios.

\section{Life cycle impact assessment (LCIA)}

The LCA methods (The ReCiPe 2008 Midpoint (H) V1.13) and Umberto LCA+ software were used to evaluate the impact categories. The impact categories selected were climate changes, photochemical oxidant formation, freshwater eutrophication, terrestrial acidification, freshwater ecotoxicity, terrestrial ecotoxicity, human toxicity and particulate matter formation. These impact categories were selected because the groundwater and surface water are the main sources of water in Arusha City and therefore emissions from the proposed MSW treatment might be detrimental to water sources, land and air.

\section{Sensitivity analysis}

The sensitivity analysis focused on assessing whether improvement on the process which mostly contributed to impact categories would result in an improvement on impact categories. This was achieved through assuming an increase of $5 \%$ improvement on different process and recovery of the resources in scenarios, and then the variability (in terms of range) upon improvement was determined. Another sensitivity analysis performed aimed at evaluating the reliability of the ReCiPe 2008 Midpoint (H) V1.13 LCIA results obtained. This was achieved by comparing the LCIA results obtained from ReCiPe 2008 Midpoint (H). V1.13 with the results obtained from intergovernmental panel on climate change (IPCC 2013) and international life cycle data system (ILCD 2.02018) LCIA methodologies [30, 31].

\section{Results and discussion}

\section{Environmental impacts of systems without resources} recovery

Table 4 depicts the environmental impact of each scenario without the electricity and compost recovery. SN-1 showed high environmental impacts on most categories except for the human toxicity, particulate matter formation and terrestrial acidification. The high environmental impacts on $\mathrm{SN}-1$ could be attributed by direct methane emissions and diesel consumptions during the compaction process. The decomposition of the biodegradable wastes produces emissions in all scenarios. Most of the methane generated in a landfill is not captured resulting in high climate change and photochemical oxidant formation in $\mathrm{SN}-1$ than in composting $(\mathrm{SN}-2)$ and anaerobic digestion (SN-3). Similar observations were indicated by Maalouf and El-Fadel [32], who indicated that methane emissions in a landfill are the major contributor for climate change and photochemical oxidant formation. Thus, diverting the organic waste fractions to composting or anaerobic digestion process would significantly reduce the climate change and photochemical oxidant formation. $\mathrm{SN}-1$ has also a higher terrestrial ecotoxicity in a comparison with other scenarios due to higher diesel consumptions since all wastes are assumed to be compacted during the landfilling process. Whereas in $\mathrm{SN}-2$ and $\mathrm{SN}-3$ wastewater emissions were not considered, but $\mathrm{SN}-1$ resulted in higher freshwater eutrophication due to total nitrogen and total phosphorus nutrients emissions. Landfilling of papers and plastics was the dominant factor for human toxicity and freshwater ecotoxicity in all scenarios. Since the same amount of papers and plastics is assumed to be landfilled in all scenarios, there are slight differences in impact categories of human toxicity and freshwater ecotoxicity among scenarios. For composting (SN-2) ammonia emission was a dominant factor for particulate matter formation and terrestrial acidification impact categories. The large fraction of the nitrogen is lost as ammonia during the composting process causing high ammonia emission in composting $(\mathrm{SN}-2)$ than in landfill $(\mathrm{SN}-1)$ and $\mathrm{AD}(\mathrm{SN}-$ 3) [22]. The literature points out that environmental emission minimization in a composting process can be achieved through properly blending of the feedstock to achieve the required carbon to nitrogen ratio of 20-40 for fast composting, use of the odor removal devices, and promotion of home composting to minimize emissions due to transport process $[4,22]$. Besides landfilling of paper and plastics in SN-3, electricity consumptions, ammonia and methane emissions were the dominant factors for freshwater eutrophication, particulate matter formation, and climate change, respectively. In anaerobic digestion ( $\mathrm{SN}-3)$ high amount of methane is generated but the high percentage is captured for an electricity generation [25]. The methane generation in composting (SN-2) is very low as compared to the landfill (SN-1), and anaerobic digestion ( $\mathrm{SN}-3)$ in a such a way that some pieces of literature assume no $\mathrm{CH}_{4}$ is emitted during the composting process [16].

Figure 2 indicates the percentage of contributions of the major substances to the impact categories. Results showed that for freshwater eutrophication, phosphorus was a dominant contributor for $\mathrm{SN}-1$, phosphate for $\mathrm{SN}$ 2 and electricity for SN-3. For the all scenarios Manganese contributed most to human toxicity. For particulate 
Table 4 Environmental impacts of systems without resources recovery

\begin{tabular}{|c|c|c|c|c|c|c|c|}
\hline \multirow[t]{2}{*}{ Category } & \multirow[t]{2}{*}{ Unit } & \multicolumn{2}{|c|}{ SN-1 (RCL_LF) } & \multicolumn{2}{|c|}{ SN-2 (RCL_CP_LF) } & \multicolumn{2}{|c|}{ SN-3 (RCL_AD_LF) } \\
\hline & & Value & Process & Value & Process & Value & Process \\
\hline \multirow[t]{2}{*}{ Fresh water eutrophication } & kg P eq & 4.5 & Nutrients (99\%) & $\begin{array}{l}6.4 \times 10 \\
-4\end{array}$ & Phosphate (81\%) & $\int_{-3}^{1.7 \times 10}$ & Electricity (64\%) \\
\hline & & & & & Diesel (18\%) & & Phosphate (28\%) \\
\hline \multirow[t]{2}{*}{ Human toxicity } & kg1,4-DCB eq & 10.9 & LF of papers (69\%) & 10.5 & LF of papers (71\%) & 11.2 & LF of papers (67\%) \\
\hline & & & LF of plastics (21\%) & & LF of plastics (22\%) & & LF of plastics (21\%) \\
\hline Particulate matter formation & $\mathrm{kg} \mathrm{PM} 10$ & 0.05 & Diesel (80\%) & 0.44 & $\mathrm{NH}_{3}(93 \%)$ & 0.28 & $\mathrm{NH}_{3}(82 \%)$ \\
\hline \multirow[t]{2}{*}{ Fresh water ecotoxicity } & $\begin{array}{l}\mathrm{kg} 1,4-\mathrm{DCB} \\
\text { eq }\end{array}$ & 0.86 & LF of papers (46.5\%) & 0.83 & LF of papers (48\%) & 0.86 & LF of papers $(46 \%)$ \\
\hline & & & $\begin{array}{l}\text { LF of plastics } \\
(43.0 \%)\end{array}$ & & LF of plastics (45\%) & & LF of plastics (43\%) \\
\hline Climate change & $\mathrm{kg} \mathrm{CO} \mathrm{CO}_{2}$ eq & 1305 & $\mathrm{CH}_{4}$ emission (94\%) & 91 & $\mathrm{CH}_{4}$ emission (93\%) & 274 & $\begin{array}{l}\mathrm{CH}_{4} \text { emission } \\
(97 \%)\end{array}$ \\
\hline \multirow[t]{2}{*}{ Terrestrial ecotoxicity } & $\begin{array}{l}\mathrm{kg} 1,4-\mathrm{DCB} \\
\text { eq }\end{array}$ & ${ }_{-3}^{1.1} \times 10$ & Diesel 35\%) & $\frac{8.7 \times 10}{-4}$ & Transport (36\%) & $\frac{8.9 \times 10}{-4}$ & Transport (35\%) \\
\hline & & & $\begin{array}{l}\text { Transport }(27 \%) \\
\text { LF of plastics (24\%) }\end{array}$ & & LF of plastics (32\%) & & LF of plastics (31\%) \\
\hline \multirow[t]{3}{*}{$\begin{array}{l}\text { Photochemical oxidant } \\
\text { formation }\end{array}$} & $\begin{array}{l}\text { kg NMVOC } \\
\text { eq }\end{array}$ & 0.74 & $\mathrm{CH}_{4}(76 \%)$ & 0.14 & Diesel (28.5\%) & 0.3 & $\mathrm{NO}_{2}(43 \%)$ \\
\hline & & & Diesel (18\%) & & $\mathrm{NO}_{2}(28.5 \%)$ & & $\begin{array}{l}\mathrm{CH}_{4} \text { emission } \\
(40 \%)\end{array}$ \\
\hline & & & & & $\begin{array}{l}\mathrm{CH}_{4} \text { emission } \\
(21.4 \%)\end{array}$ & & Diesel (10\%) \\
\hline Terrestrial acidification & $\mathrm{kg} \mathrm{SO}_{2}$ eq & 0.11 & Diesel (64\%) & 3.18 & $\mathrm{NH}_{3}$ emission (98\%) & 1.86 & $\begin{array}{l}\mathrm{NH}_{3} \text { emission } \\
(94 \%)\end{array}$ \\
\hline
\end{tabular}

SN Scenario, $R C L$ Recycling, LF Landfilling, CP Composting, $A D$ Anaerobic digestion, $D C B$ Dichlorobenzene, NMVOC Non-methane volatile organic compounds

matter formation and terrestrial acidification, ammonia was the dominant factor for SN-2 and SN-3, while diesel was a dominant factor for $\mathrm{SN}-1$. For all scenarios, copper was the dominant contributor to freshwater ecotoxicity. In climate change, methane was the main contributor to all scenarios. In terrestrial ecotoxicity, diesel was the main contributor for $\mathrm{SN}-2$ and $\mathrm{SN}-3$. In photochemical oxidant formation, methane contributed most in $\mathrm{SN}-1$, whereas nitrogen oxides contributed most in $\mathrm{SN}-2$ and $\mathrm{SN}-3$.

\section{Impact of the resource recovery}

Tables 5 and 6 depict the environmental impacts for producing hydropower electricity and mineral fertilizer computed from ecoinvent v.3.6 of the Umberto software. The avoided environmental burdens were subtracted from the total environmental burdens without resource recovery and their results are shown in Table 7. Results indicated that incorporating resources recovery resulted in improved environmental burdens, although it did not alter the ranking of categories in most impact categories. In anaerobic digestion ( $\mathrm{SN}-3)$, the digestate recovery when compared with the recovery of electricity contributed to most impact categories except for freshwater ecotoxicity and climate change of which electricity was the main factor. The lower contribution by electricity recovery in $\mathrm{SN}-3$ is attributed to the fact that the hydrobased power source considered in the analysis in comparisons to other power sources, has lower environmental emissions [33]. The avoided emissions resulting from producing chemical fertilizers $\left(\mathrm{N}, \mathrm{P}_{2} \mathrm{O}_{5}\right.$, and $\mathrm{K}_{2} \mathrm{O}$ ) as a result of composting and digestate recovery in $\mathrm{SN}-2$ and $\mathrm{SN}-3$ affected mostly human toxicity impact making $\mathrm{SN}-3$ much better than $\mathrm{SN}-1$, whereas $\mathrm{SN}-2$ remained the most favored scenario in this category. Further comparisons of the economic estimates of each scenario were made based on the economic costs given in Table 8 [7]. From the computation, the Scenario $\mathrm{SN}-2$ was found to have a low economic cost of 47 USD $\mathrm{t}^{-1}$, followed by Scenario SN-1(54 USD $\mathrm{t}^{-1}$ ) and SN-4 $\left(70 \mathrm{USD}^{-1}\right.$ ). The scenario SN-3 had the high economic

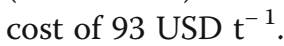

\section{Sensitivity analysis}

\section{Sensitivity to processes improvement}

The sensitivity results indicated in Table 9 show that reducing methane emissions to the environment brought environmental benefits in all scenarios of which $\mathrm{SN}-1$ was highly impacted. The impacted categories were climate changes in all scenarios, photochemical oxidant 

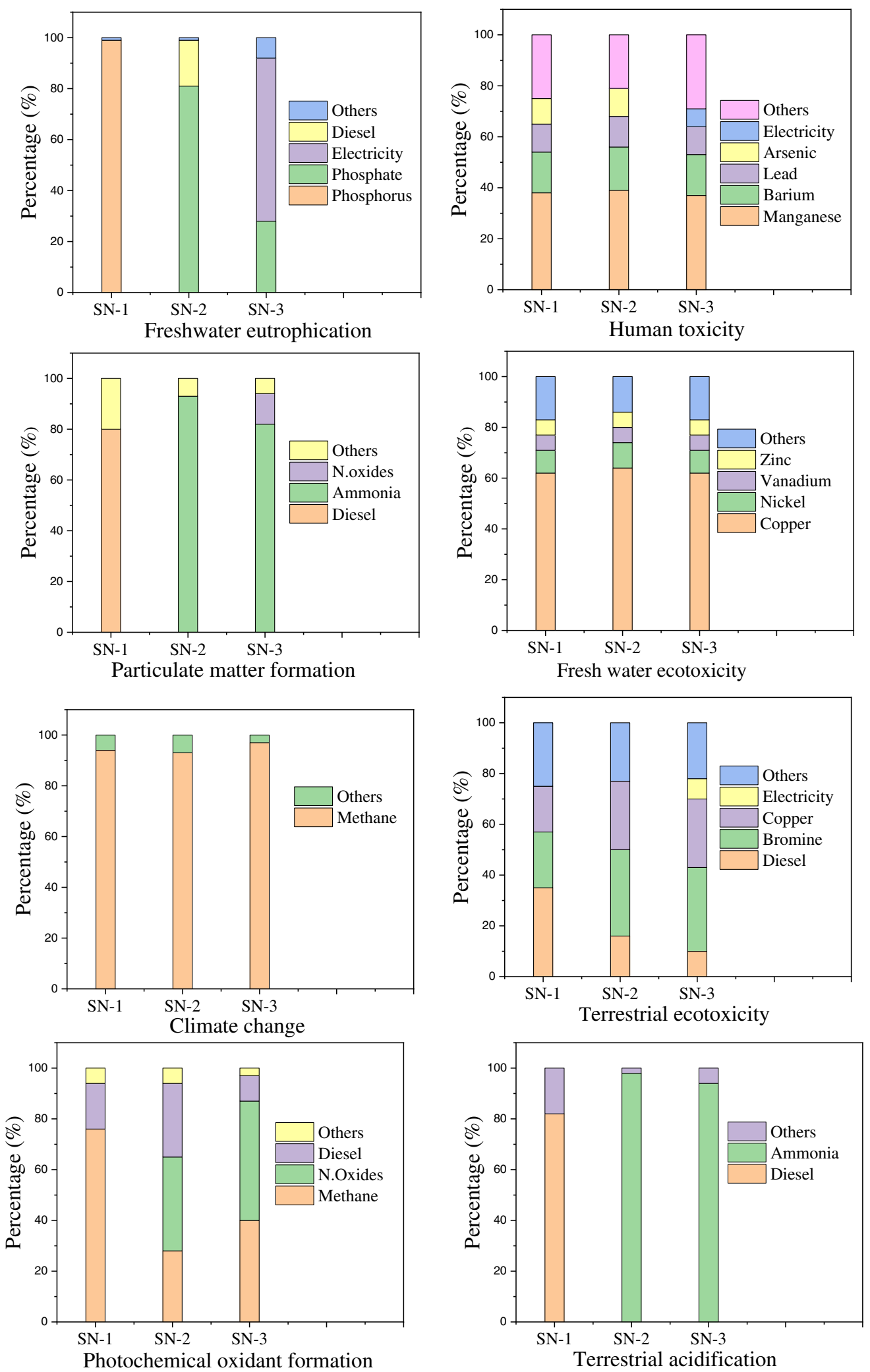

Fig. 2 Percentage contributions of the major substances to the impact categories 
Table 5 Environmental impacts from the production of hydropower electricity (Ecoinvent v.3.6 database)

\begin{tabular}{|c|c|c|c|c|}
\hline \multirow[t]{3}{*}{ Category } & \multirow[t]{3}{*}{ Unit } & \multicolumn{3}{|l|}{ Value } \\
\hline & & $1 \mathrm{kWh}^{*}$ & $43.55 \mathrm{kWh}^{*}$ & $135.35 \mathrm{kWh}^{\mathrm{a}}$ \\
\hline & & & SN-1 (RCL_LF) & SN-3 (RCL_AD_LF) \\
\hline Fresh water eutrophication & $\mathrm{kg} P$ eq & $1.6 \times 10^{-6}$ & $6.8 \times 10^{-5}$ & $2.1 \times 10^{-4}$ \\
\hline Human toxicity & $\mathrm{kg1} 1,4-\mathrm{DCB}$ eq & $2.1 \times 10^{-3}$ & 0.09 & 0.28 \\
\hline Particulate matter formation & $\mathrm{kg} \mathrm{PM} 10$ & $2.1 \times 10^{-5}$ & $9.0 \times 10^{-4}$ & $2.8 \times 10^{-3}$ \\
\hline Fresh water ecotoxicity & $\mathrm{kg} 1,4-\mathrm{DCB}$ eq & $1.8 \times 10^{-4}$ & $8.0 \times 10^{-3}$ & 0.03 \\
\hline Climate change & $\mathrm{kg} \mathrm{CO}_{2}$ eq & 0.06 & 2.83 & 8.91 \\
\hline Terrestrial ecotoxicity & $\mathrm{kg} 1,4-\mathrm{DCB}$ eq & $5.3 \times 10^{-7}$ & $2.3 \times 10^{-5}$ & $7.3 \times 10^{-5}$ \\
\hline Photochemical oxidant formation & kg NMVOC eq & $3.8 \times 10^{-5}$ & $1.7 \times 10^{-3}$ & $5.2 \times 10^{-3}$ \\
\hline Terrestrial acidification & $\mathrm{kg} \mathrm{SO}_{2}$ eq & $2.1 \times 10^{-5}$ & $9.2 \times 10^{-4}$ & $2.9 \times 10^{-3}$ \\
\hline
\end{tabular}

SN Scenario, RCL Recycling, LF Landfilling, CP Composting, $A D$ Anaerobic digestion, $D C B$ Dichlorobenzene, NMVOC Non-methane volatile organic compounds ${ }^{a}$ Quantity of hydropower electricity contributing to the environmental impacts

formation in SN-1 and SN-3 and terrestrial acidification in SN-1. Improving electricity consumption efficiency had the highest environmental impact benefits in SN-3 and impacted on impact categories of freshwater eutrophication, human toxicity, climate change and terrestrial ecotoxicity. In $\mathrm{SN}-1$ efficiency of electricity, consumptions brought some environmental benefits only in climate change and had no impact on SN-2. Reducing ammonia emissions had lower impacts in most categories except for the particulate matter formation and terrestrial acidification in $\mathrm{SN}-2$ and $\mathrm{SN}-3$. Improving recycling of paper and plastics exhibited higher environmental impacts in most categories of all the scenarios except for the particulate matter formation, photochemical oxidant formation and terrestrial acidification. Improvement on diesel consumption had a high impact on $\mathrm{SN}-1$ in most categories except for freshwater eutrophication, particulate matter formation and freshwater

Table 6 Environmental impacts from the production of mineral fertilizers options (Ecoinvent v.3.6 database)

\begin{tabular}{|c|c|c|c|c|c|c|}
\hline \multirow[t]{2}{*}{ Category } & \multirow[t]{2}{*}{ Unit } & & \multicolumn{3}{|l|}{ Value } & \multirow[t]{2}{*}{ Total } \\
\hline & & & Fertilizer (Nitrogen) & $\begin{array}{l}\text { Fertilizer } \\
\text { (Phosphate) }\end{array}$ & $\begin{array}{l}\text { Fertilizer } \\
\text { (Potassium) }\end{array}$ & \\
\hline \multirow[t]{2}{*}{ Fresh water eutrophication } & $\mathrm{kg} P$ eq & $\mathrm{SN}-2$ & $5.1 \times 10^{-4}$ & $7.8 \times 10^{-4}$ & $1.2 \times 10^{-4}$ & $1.4 \times 10^{-3}$ \\
\hline & & $\mathrm{SN}-3$ & $6.3 \times 10^{-4}$ & $4.3 \times 10^{-4}$ & $2.0 \times 10^{-5}$ & $1.1 \times 10^{-3}$ \\
\hline \multirow[t]{2}{*}{ Human toxicity } & kg1,4-DCB eq & $\mathrm{SN}-2$ & 0.99 & 0.54 & 0.19 & 1.7 \\
\hline & & $\mathrm{SN}-3$ & 1.2 & 0.3 & 0.03 & 1.6 \\
\hline \multirow[t]{2}{*}{ Particulate matter formation } & $\mathrm{kg} \mathrm{PM} 10$ & $\mathrm{SN}-2$ & $4.9 \times 10^{-3}$ & $3.7 \times 10^{-3}$ & $1.4 \times 10^{-3}$ & $1.0 \times 10^{-2}$ \\
\hline & & $\mathrm{SN}-3$ & $6.1 \times 10^{-3}$ & $2.0 \times 10^{-3}$ & $2.4 \times 10^{-4}$ & $8.4 \times 10^{-3}$ \\
\hline \multirow[t]{2}{*}{ Fresh water ecotoxicity } & $\mathrm{kg} \mathrm{1,4-DCB} \mathrm{eq}$ & $\mathrm{SN}-2$ & 0.15 & 0.07 & 0.02 & $2.4 \times 10^{-1}$ \\
\hline & & $\mathrm{SN}-3$ & 0.18 & 0.04 & $3.02 \times 10^{-3}$ & $2.2 \times 10^{-1}$ \\
\hline \multirow[t]{2}{*}{ Climate change } & $\mathrm{kg} \mathrm{CO}_{2}$ eq & $\mathrm{SN}-2$ & 3.6 & 0.7 & 0.68 & 5.0 \\
\hline & & $\mathrm{SN}-3$ & 4.5 & 0.38 & 0.12 & 5.0 \\
\hline \multirow[t]{2}{*}{ Terrestrial ecotoxicity } & $\mathrm{kg} \mathrm{1,4-DCB} \mathrm{eq}$ & $\mathrm{SN}-2$ & $2.8 \times 10^{-4}$ & $2.8 \times 10^{-4}$ & $1.2 \times 10^{-4}$ & $6.8 \times 10^{-4}$ \\
\hline & & $\mathrm{SN}-3$ & $3.5 \times 10^{-4}$ & $1.5 \times 10^{-4}$ & $2.1 \times 10^{-5}$ & $5.2 \times 10^{-4}$ \\
\hline \multirow[t]{2}{*}{ Photochemical oxidant formation } & $\mathrm{kg}$ NMVOC eq & $\mathrm{SN}-2$ & $9.0 \times 10^{-3}$ & $3.2 \times 10^{-3}$ & $3.3 \times 10^{-3}$ & $1.5 \times 10^{-2}$ \\
\hline & & $\mathrm{SN}-3$ & 0.01 & $1.7 \times 10^{-3}$ & $5.6 \times 10^{-4}$ & $1.2 \times 10^{-2}$ \\
\hline \multirow[t]{2}{*}{ Terrestrial acidification } & $\mathrm{kg} \mathrm{SO}_{2}$ eq & $\mathrm{SN}-2$ & 0.02 & $7.7 \times 10^{-3}$ & $3.6 \times 10^{-3}$ & $3.1 \times 10^{-2}$ \\
\hline & & $\mathrm{SN}-3$ & 0.02 & $4.2 \times 10^{-3}$ & $6.1 \times 10^{-4}$ & $2.5 \times 10^{-2}$ \\
\hline
\end{tabular}

SN-2; (RCL_CP_LF) and SN-3; (RCL_AD_LF), where RCL Recycling, LF Landfilling, CP Composting, AD Anaerobic digestion, DCB Dichlorobenzene, NMVOC Nonmethane volatile organic compounds 
Table 7 Environmental impacts results with resources recovery

\begin{tabular}{lllll}
\hline Category & Unit & $\begin{array}{l}\text { SN-1 } \\
\text { (RCL_LF) } \\
\text { Value }\end{array}$ & SN-2 (RCL_CP_LF) & SN-3 (RCL_AD_LF) \\
\hline Fresh water eutrophication & & 4.5 & $-7.7 \times 10^{-4}$ & $3.7 \times 10^{-4}$ \\
Human toxicity & $\mathrm{kg} \mathrm{P} \mathrm{eq}$ & 11 & 8.7 & 9.3 \\
Particulate matter formation & $\mathrm{kg} 1,4-\mathrm{DCB}$ eq & 0.049 & 0.43 & 0.27 \\
Fresh water ecotoxicity & $\mathrm{kg} \mathrm{PM} 10$ & 0.85 & 0.59 & 0.61 \\
Climate change & $\mathrm{kg} \mathrm{1,4-DCB} \mathrm{eq}$ & 1303 & 86 & 260 \\
Terrestrial ecotoxicity & $\mathrm{kg} \mathrm{CO}$ eq & $1.1 \times 10^{-3}$ & $1.9 \times 10^{-4}$ & $2.9 \times 10^{-4}$ \\
Photochemical oxidant formation & $\mathrm{kg} \mathrm{1,4-DCB}$ eq & 0.74 & 0.13 & 0.28 \\
Terrestrial acidification & $\mathrm{kg} \mathrm{NMVOC}$ eq & 0.11 & 3.2 & 1.8 \\
\hline
\end{tabular}

SN Scenario, RCL Recycling, LF Landfilling, CP Composting, AD Anaerobic digestion, DCB Dichlorobenzene, NMVOC Non-methane volatile organic compounds

Table 8 The average economic cost of MSW treatment options (USD t $\left.{ }^{-1}\right)$ [7]

\begin{tabular}{llllll}
\hline Treatment option & Organic waste & Plastic & Paper & Glass & Others \\
\hline Recycling & - & 93.9 & -67 & 20.1 & - \\
Landfill & 58.3 & 71.1 & 67.3 & 70.3 & 68.3 \\
Composting & 47 & - & - & - & - \\
Anaerobic digestion & 115.3 & - & - & - & - \\
\hline
\end{tabular}

ecotoxicity. In $\mathrm{SN}-2$ and $\mathrm{SN}-3$ the improvement on diesel consumptions had an impact on climate change, terrestrial ecotoxicity, freshwater eutrophication (only $\mathrm{SN}-2$ ) and human toxicity (only SN-3). Generally, we can observe that improving diesel consumptions, reducing methane emissions to air and increasing recycling rate of papers and plastics are the main factors that would impact all scenarios.

Table 9 Sensitivity analysis on 5\% improvement of process and resources recoveries

\begin{tabular}{|c|c|c|c|c|c|c|c|c|}
\hline Categories & Unit & & Electricity & $\mathrm{CH}_{4}$ & Diesel & Paper & Plastic & $\overline{\mathrm{NH}_{3}}$ \\
\hline \multirow[t]{3}{*}{ Freshwater eutrophication } & $\mathrm{kg} P$ eq & $\mathrm{SN}-1$ & - & - & - & - & - & - \\
\hline & & $\mathrm{SN}-2$ & - & - & $6 \times 10^{-6}$ & $2 \times 10^{-5}$ & $1 \times 10^{-6}$ & - \\
\hline & & $\mathrm{SN}-3$ & $5 \times 10^{-5}$ & - & - & $2 \times 10^{-5}$ & - & - \\
\hline \multirow[t]{3}{*}{ Human toxicity } & $\mathrm{kg} 1,4-\mathrm{DCB}$ eq & $\mathrm{SN}-1$ & - & - & 0.02 & 0.41 & 0.11 & - \\
\hline & & $\mathrm{SN}-2$ & - & - & - & 0.4 & 0.11 & - \\
\hline & & $\mathrm{SN}-3$ & 0.04 & - & 0.01 & 0.41 & 0.12 & - \\
\hline \multirow[t]{3}{*}{ Particulate matter formation } & $\mathrm{kg} \mathrm{PM}_{10}$ & $\mathrm{SN}-1$ & - & - & - & - & - & - \\
\hline & & $\mathrm{SN}-2$ & - & - & - & - & - & 0.02 \\
\hline & & $\mathrm{SN}-3$ & - & - & - & - & - & 0.01 \\
\hline \multirow[t]{3}{*}{ Freshwater ecotoxicity } & kg 1,4-DCB eq & $\mathrm{SN}-1$ & - & - & - & 0.02 & 0.02 & - \\
\hline & & $\mathrm{SN}-2$ & - & - & - & 0.02 & 0.02 & - \\
\hline & & $\mathrm{SN}-3$ & - & - & - & 0.02 & 0.02 & - \\
\hline \multirow[t]{3}{*}{ Climate change } & $\mathrm{kg} \mathrm{CO}$ eq & $\mathrm{SN}-1$ & 0.02 & 61 & 0.49 & 3.7 & 0.03 & - \\
\hline & & $\mathrm{SN}-2$ & - & 0.93 & 0.18 & 3.7 & 0.03 & - \\
\hline & & $\mathrm{SN}-3$ & 0.1 & 10 & 0.1 & 3.7 & 0.03 & - \\
\hline \multirow[t]{3}{*}{ Terrestrial ecotoxicity } & $\mathrm{kg} 1,4-\mathrm{DCB}$ eq & $\mathrm{SN}-1$ & - & - & $2 \times 10^{-5}$ & $1 \times 10^{-5}$ & $1 \times 10^{-5}$ & - \\
\hline & & $\mathrm{SN}-2$ & - & - & $8 \times 10^{-6}$ & $6 \times 10^{-6}$ & $1.4 \times 10^{-5}$ & - \\
\hline & & $\mathrm{SN}-3$ & $3 \times 10^{-6}$ & - & $4 \times 10^{-6}$ & $6 \times 10^{-6}$ & $1.4 \times 10^{-5}$ & - \\
\hline \multirow[t]{3}{*}{ Photochemical oxidant formation } & kg NMVOC eq & $\mathrm{SN}-1$ & - & 0.03 & 0.01 & - & - & - \\
\hline & & $\mathrm{SN}-2$ & - & - & - & - & - & - \\
\hline & & $\mathrm{SN}-3$ & - & 0.01 & - & - & - & - \\
\hline \multirow[t]{3}{*}{ Terrestrial acidification } & $\mathrm{kg} \mathrm{SO}_{2}$ eq & $\mathrm{SN}-1$ & - & 0.01 & 0.01 & - & - & - \\
\hline & & $\mathrm{SN}-2$ & - & - & - & - & - & 0.16 \\
\hline & & $\mathrm{SN}-3$ & - & - & - & - & - & 0.08 \\
\hline
\end{tabular}




\section{Sensitivity to $L C I A$ methods}

ILCD 2.02018 midpoint and IPCC 2013 impact methods were used for the comparison of the results obtained in ReCiPe 2008 Midpoint (H) V1.13 as indicated in Table 10. The results of ILCD 2.02018 midpoint and IPCC 2013 were similar to those of ReCiPe in the photochemical oxidant formation, and freshwater eutrophication. For the climate change, the LCIA results obtained from ILCD 2.02018 midpoint and IPCC 2013 were higher than those from ReCiPe. The difference in results could be attributed by the fact that the ILCD adapted the IPCC 2013 model with the carbon feedbacks of which the methane's 100 -yr global warming potential is 34, the IPCC 2013 method in ecoinvent V3.6 of Umberto software database has the methane's 100-yr potential of 28 (with no carbon adjustment) and with ReCiPe method, it considers the methane's 100-yr global warming potential to be 22 [34]. For freshwater ecotoxicity and terrestrial acidification, it was difficult to compare LCIA results obtained from ReCiPe to those of ILCD 2.02018 because of the units used and the failure to obtain their conversion factors. Other factors such as human toxicity, particulate matter formation, and terrestrial ecotoxicity were not compared because in ILCD 2.02018 and IPCC 2013 are not quantified. Another limitation on assessing the impact methods was due to the licence limitation of the Umberto software that had only a few updated LCIA methods from ecoinvent database version 3.6. Based on the comparisons made between ReCiPe, ILCD 2.02018 and IPCC 2013 methods, the ReCiPe was consistent for photochemical oxidant formation and freshwater eutrophication.

\section{Conclusions}

This study analyzed the environmental impacts of MSW management scenarios in Arusha city of Tanzania. When the resources recovery is considered, the BAU scenario $\mathrm{SN}-1$ which is the combination of the recycling and landfill leads to the most adverse environmental burdens in most categories analyzed except for particulate matter formation and terrestrial acidification. When $\mathrm{SN}-2$ and $\mathrm{SN}-3$ are compared upon resources recovery, the $\mathrm{SN}-2$ which is the combination of the recycling, composting and landfill performed better in most impact

Table 10 Compared ReCiPe 2008 Midpoint (H) V1.13 results with other LCIA methods without resources recovery

\begin{tabular}{|c|c|c|c|c|c|}
\hline Category & Unit & & ReCiPe & ILCD & IPCC 2013 \\
\hline \multirow[t]{3}{*}{ Fresh water eutrophication } & $\mathrm{kg} P$ eq & SN-1 & 4.5 & 4.5 & - \\
\hline & & $\mathrm{SN}-2$ & $6.4 \times 10^{-4}$ & $6.4 \times 10^{-4}$ & - \\
\hline & & $\mathrm{SN}-3$ & $1.7 \times 10^{-3}$ & $1.7 \times 10^{-3}$ & - \\
\hline \multirow[t]{3}{*}{ Human toxicity } & kg1,4-DCB eq & $\mathrm{SN}-1$ & 10.9 & - & - \\
\hline & & $\mathrm{SN}-2$ & 10.5 & - & - \\
\hline & & $\mathrm{SN}-3$ & 11.2 & - & - \\
\hline \multirow[t]{3}{*}{ Particulate matter formation } & $\mathrm{kg} \mathrm{PM}_{10}$ & $\mathrm{SN}-1$ & 0.05 & - & - \\
\hline & & $\mathrm{SN}-2$ & 0.44 & - & - \\
\hline & & $\mathrm{SN}-3$ & 0.28 & - & - \\
\hline \multirow[t]{3}{*}{ Fresh water ecotoxicity } & kg 1,4-DCB eq & $\mathrm{SN}-1$ & 0.86 & $6.2 \mathrm{CTU}$ & - \\
\hline & & $\mathrm{SN}-2$ & 0.83 & $4.7 \mathrm{CTU}$ & - \\
\hline & & $\mathrm{SN}-3$ & 0.86 & $5.0 \mathrm{CTU}$ & - \\
\hline \multirow[t]{3}{*}{ Climate change } & $\mathrm{kg} \mathrm{CO}{ }_{2}$ eq & $\mathrm{SN}-1$ & 1305 & 1984 & 1665 \\
\hline & & $\mathrm{SN}-2$ & 91 & 136 & 115 \\
\hline & & $\mathrm{SN}-3$ & 274 & 414 & 348 \\
\hline \multirow[t]{3}{*}{ Terrestrial ecotoxicity } & $\mathrm{kg} 1,4-\mathrm{DCB}$ eq & $\mathrm{SN}-1$ & $1.1 \times 10^{-3}$ & - & - \\
\hline & & $\mathrm{SN}-2$ & $8.7 \times 10^{-4}$ & - & - \\
\hline & & $\mathrm{SN}-3$ & $8.9 \times 10^{-4}$ & - & - \\
\hline \multirow[t]{3}{*}{ Photochemical oxidant formation } & kg NMVOC eq & $\mathrm{SN}-1$ & 0.74 & 0.74 & - \\
\hline & & $\mathrm{SN}-2$ & 0.14 & 0.14 & - \\
\hline & & $\mathrm{SN}-3$ & 0.3 & 0.3 & - \\
\hline \multirow[t]{3}{*}{ Terrestrial acidification } & $\mathrm{kg} \mathrm{SO}_{2}$ eq & $\mathrm{SN}-1$ & 0.11 & $0.14 \mathrm{~mol} \mathrm{H}^{+}$eq & - \\
\hline & & $\mathrm{SN}-2$ & 3.3 & $3.9 \mathrm{~mol} \mathrm{H}^{+}$eq & - \\
\hline & & $\mathrm{SN}-3$ & 1.9 & $2.3 \mathrm{~mol} \mathrm{H}^{+}$eq & - \\
\hline
\end{tabular}


assessment except for particulate matter and terrestrial acidifications. Further comparisons in economic cost reveal that $\mathrm{SN}-2$ would be more preferable than all scenarios. Therefore, although the final choice of the best scenario would depend on assigned weights in impact categories, in developing countries where there are lack of funds and recent attention by the public on climate change, the $\mathrm{SN}-2$ would be the best option among all the scenarios evaluated.

\section{Acknowledgements \\ The authors would like to thank the African Development Bank (AFDB) and Nelson Mandela African Institution of Science and Technology (NM-AIST) for the conducive environment during the study. The authors also would like to acknowledge the use of the Joint Undertaking for an African Materials Institute (JUAMI) Open Computing Facility (OCF) server to complete the life cycle assessment modelling using Umberto. Software licensing support came from the UN Environment Program (UNEP) LCA Award, University of Michigan College of Engineering and the Dow Distinguished Awards program. The authors also acknowledge Mr. Brian lezzi of the University of Michigan, the USA for his contributions in this manuscript.}

\section{Authors' contributions}

All authors read and approved the final manuscript.

\section{Funding}

This work was supported by the African Development Bank (AFDB), Project No. P-Z1-IA0-016 and grant No. 2100155032816.

\section{Availability of data and materials}

All data generated or analyzed during this study are within the submitted manuscript.

\section{Competing interests}

The authors declare they have no competing interests.

\section{Author details}

'Department of Water and Environmental Science and Engineering, Nelson Mandela African Institution of Science and Technology, 23311 Arusha, Tanzania. ${ }^{2}$ Department of Water Resources Engineering, University of Dar es Salaam, 16103 Dar es Salaam, Tanzania. ${ }^{3}$ Department of Materials Science and Engineering, Nelson Mandela African Institution of Science and Technology, 23311 Arusha, Tanzania.

Received: 8 July 2020 Accepted: 3 December 2020

Published online: 07 January 2021

\section{References}

1. Kaza S, Yao L, Bhada-Tata P, Van Woerden F. What a waste 2.0: a global snapshot of solid waste management to 2050. Washington, DC: World Bank; 2018.

2. $\mathrm{Xu} C Q$, Shi WX, Hong JL, Zhang FF, Chen W. Life cycle assessment of food waste-based biogas generation. Renew Sust Energ Rev. 2015;49:169-77.

3. Khandelwal $H$, Thalla AK, Kumar S, Kumar R. Life cycle assessment of municipal solid waste management options for India. Bioresour Technol. 2019:288:121515.

4. Oyoo R, Leemans R, Mol APJ. Comparison of environmental performance for different waste management scenarios in East Africa: the case of Kampala City, Uganda. Habitat Int. 2014;44:349-57.

5. Dong J, Chi Y, Zou DA, Fu C, Huang QX, Ni MJ. Comparison of municipal solid waste treatment technologies from a life cycle perspective in China. Waste Manage Res. 2014;32:13-23.

6. Pires A, Chang NB, Martinho G. Reliability-based life cycle assessment for future solid waste management alternatives in Portugal. Int J Life Cycle Ass. 2011;16:316-37.

7. Richard EN, Hilonga A, Machunda RL, Njau KN. A review on strategies to optimize metabolic stages of anaerobic digestion of municipal solid wastes towards enhanced resources recovery. Sustain Environ Res. 2019;29:36.
8. Kazuva E, Zhang JQ. Analyzing municipal solid waste treatment scenarios in rapidly urbanizing cities in developing countries: the case of Dar es Salaam Tanzania. Int J Env Res Pub He. 2019;16:2035.

9. Akram M, llyas F, Garg H. Multi-criteria group decisionmaking based on ELECTRE I method in Pythagorean fuzzy information. Soft Comput. 2020;24: 3425-53.

10. Yu XH, Zhang SJ, Liao XL, Qi XL. ELECTRE methods in prioritized MCDM environment. Inform Sciences. 2018;424:301-16.

11. Omari AM, Kichonge BN, John GR, Njau KN, Mtui PL. Potential of municipal solid waste, as renewable energy source - a case study of Arusha, Tanzania. Int J Renew Energ Tech Res. 2014;3:1-9.

12. ISO 14040. Environmental Management - Life Cycle Assessment - Principles and Framework. Geneva: International Organization for Standardization; 2006.

13. Moreno-Ruiz E, Valsasina L, FitzGerald D, Brunner F, Symeonidis A, Bourgault $\mathrm{G}$, et al. Documentation of Changes Implemented in the Ecoinvent Database V3.6. Zurich: ecoinvent; 2019.

14. Igoni AH, Abowei MFN, Ayotamuno MJ, Eze CL. Comparative evaluation of batch and continuous anaerobic digesters in biogas production from municipal solid waste using mathematical models. Agric Eng Int CIGR J. 2008;10:1-12.

15. Kaza S, Bhada-Tata P. Decision maker's guides for solid waste management technologies. Washington, DC: World Bank; 2018.

16. Boldrin A, Andersen JK, Moller J, Christensen TH, Favoino E. Composting and compost utilization: accounting of greenhouse gases and global warming contributions. Waste Manage Res. 2009;27:800-12.

17. Hong JL, Li XZ, Cui ZJ. Life cycle assessment of four municipal solid waste management scenarios in China. Waste Manage. 2010;30:2362-9.

18. Sharma BK, Chandel MK. Life cycle assessment of potential municipal solid waste management strategies for Mumbai India. Waste Manage Res. 2017; 35:79-91.

19. Rajaeifar MA, Tabatabaei M, Ghanavati H. Data supporting the comparative life cycle assessment of different municipal solid waste management scenarios. Data Brief. 2015:3:189-94.

20. Abduli MA, Naghib A, Yonesi M, Akbari A. Life cycle assessment (LCA) of solid waste management strategies in Tehran: landfill and composting plus landfill. Environ Monit Assess. 2011;178:487-98.

21. Amlinger F, Peyr S, Cuhls C. Green house gas emissions from composting and mechanical biological treatment. Waste Manage Res. 2008;26:47-60.

22. van Haaren R, Themelis NJ, Barlaz M. LCA comparison of windrow composting of yard wastes with use as alternative daily cover (ADC). Waste Manage. 2010;30:2649-56.

23. Rasi S, Veijanen A, Rintala J. Trace compounds of biogas from different biogas production plants. Energy. 2007:32:1375-80.

24. Odedina MJ, Charnnok B, Saritpongteeraka K, Chaiprapat S. Effects of size and thermophilic pre-hydrolysis of banana peel during anaerobic digestion, and biomethanation potential of key tropical fruit wastes. Waste Manage. 2017;68:128-38

25. Belboom S, Digneffe JM, Renzoni R, Germain A, Leonard A. Comparing technologies for municipal solid waste management using life cycle assessment methodology: a Belgian case study. Int J Life Cycle Ass. 2013;18: 1513-23.

26. Dye BJ, Simonov E, Lafitte G, Bennett K, Scarry D, Lepcha T, et al. Heritage dammed: water infrastructure impacts on world heritage sites and free flowing rivers. Moscow: Rivers without Boundaries and World Heritage Watch; 2019.

27. Lee U, Han J, Wang M. Evaluation of landfill gas emissions from municipal solid waste landfills for the life-cycle analysis of waste-to-energy pathways. J Clean Prod. 2017:166:335-42.

28. Chanton JR, Powelson DK, Green RB. Methane oxidation in landfill cover soils, is a 10\% default value reasonable? J Environ Qual. 2009;38:654-63.

29. Babu GLS, Lakshmikanthan P, Santhosh LG. Life cycle analysis of municipal solid waste (MSW) land disposal options in Bangalore City. In: International Conference on Sustainable Infrastructure. Long Beach; 2014 6-8.

30. Intergovernmental Panel on Climate Change. Climate change 2013 - the physical science basis: working group I contribution to the fifth assessment report of the Intergovernmental Panel on Climate Change. Cambridge: Cambridge University Press; 2014. p. 659-740.

31. Fazio S, Castellani V, Sala S, Schau EM, Secchi M, Zampori L, et al. Supporting Information to the Characterisation Factors of Recommended 
EF Life Cycle Impact Assessment Method. Ispra: European Commission; 2018.

32. Maalouf A, El-Fadel M. Life cycle assessment for solid waste management in Lebanon: economic implications of carbon credit. Waste Manage Res. 2019; 37:14-26.

33. Rajaeifar MA, Tabatabaei M, Ghanavati H, Khoshnevisan B, Rafiee S. Comparative life cycle assessment of different municipal solid waste management scenarios in Iran. Renew Sust Energ Rev. 2015;51:886-98.

34. Timma L, Dace E, Knudsen MT. Temporal aspects in emission accountingcase study of agriculture sector. Energies. 2020;13:800.

\section{Publisher's Note}

Springer Nature remains neutral with regard to jurisdictional claims in published maps and institutional affiliations.

- fast, convenient online submission

- thorough peer review by experienced researchers in your field

- rapid publication on acceptance

- support for research data, including large and complex data types

- gold Open Access which fosters wider collaboration and increased citations

- maximum visibility for your research: over $100 \mathrm{M}$ website views per year

At $\mathrm{BMC}$, research is always in progress. 